\title{
HVMANITAS
}

\section{Poética dos sonhos e das visões em estado de vigília - I}

Autor(es): $\quad$ Pereira, Susana Marques

Publicado por: Faculdade de Letras da Universidade de Coimbra, Instituto de Estudos

URL

persistente: URI:http://hdl.handle.net/10316.2/27908

DOI: $\quad$ DOI:http://dx.doi.org/10.14195/2183-1718_60_2

Accessed : $\quad$ 26-Apr-2023 15:07:48

A navegação consulta e descarregamento dos títulos inseridos nas Bibliotecas Digitais UC Digitalis, UC Pombalina e UC Impactum, pressupõem a aceitação plena e sem reservas dos Termos e Condições de Uso destas Bibliotecas Digitais, disponíveis em https://digitalis.uc.pt/pt-pt/termos.

Conforme exposto nos referidos Termos e Condições de Uso, o descarregamento de títulos de acesso restrito requer uma licença válida de autorização devendo o utilizador aceder ao(s) documento(s) a partir de um endereço de IP da instituição detentora da supramencionada licença.

Ao utilizador é apenas permitido o descarregamento para uso pessoal, pelo que o emprego do(s) título(s) descarregado(s) para outro fim, designadamente comercial, carece de autorização do respetivo autor ou editor da obra.

Na medida em que todas as obras da UC Digitalis se encontram protegidas pelo Código do Direito de Autor e Direitos Conexos e demais legislação aplicável, toda a cópia, parcial ou total, deste documento, nos casos em que é legalmente admitida, deverá conter ou fazer-se acompanhar por este aviso. 
humanitas

\section{Vol. LX}

IMPRENSA DA UNIVERSIDADE DE COIMBRA

COIMBRA UNIVERSITY PRESS 


\title{
POÉTICA DOS SONHOS E DAS VISÕES EM ESTADO DE VIGÍLIA - I
}

\author{
Susana Marques Pereira \\ Universidade de Coimbra \\ marquessusana@vizzavi.pt
}

\begin{abstract}
Resumo
A par da semelhança a nível de conteúdo e de estrutura, os sonhos e as visões em estado de vigília aproximam-se igualmente em termos estilísticos, reflectindo, também através da linguagem, a evolução de ambos os motivos, desde a épica homérica, até à comédia aristofânica (cf. afastamento progressivo da interferência directa e manifesta do mundo divino na vida humana). No presente artigo analisam-se os termos escolhidos por distintos autores/ géneros literários para 'sonho' e 'visão', bem como as respectivas implicações; os adjectivos, verbos e construções sintácticas com eles relacionados de forma mais imediata; a formulação mais ou menos ambígua da mensagem veiculada, em consonância com o propósito por ela visado.

Palavras-chave: etimologia, formulação clara da mensagem, ambiguidade de linguagem.

\section{Abstract}

Together with the similarities in content and structure, the dreams and the visions in awake state resemble each other in style as well, reflecting, also through language, the evolution of both motifs, from the Homeric epics to the comedy of Aristophanes (cf. the progressive distance between the direct
\end{abstract}

* O corpus de textos considerado neste artigo contempla a épica homérica, a lírica grega da época arcaica, Heródoto, a tragédia de Ésquilo, de Sófocles e de Eurípides e a comédia aristofânica. 
and evident interference of the divine world in human life). In this article, the terms chosen by the distinctive authors/literary genres to "dream" and "vision" are analyzed, as well as their respective implications: the adjectives, the verbs and the syntactic constructions related to them in a more immediate form; the formulation more or less ambiguous of the message conveyed, in accordance with the purpose meant.

Keywords: etymology, clear formulation of the message, ambiguous language.

Os motivos do sonho e das visões em estado de vigília propiciam naturalmente uma abordagem estilística diversificada, não apenas consoante os distintos géneros literários e contextos sócio-culturais, políticos e religiosos em que se inscrevem, como também de acordo com a sensibilidade e o propósito de cada autor que os desenvolve. A percepção dos diferentes recursos da narrativa utilizados pelos vários textos conservados, seja em termos de vocabulário e de imagens, seja ao nível discursivo, evidencia, por outro lado, a própria evolução de ambos os motivos.

A etimologia dos termos empregues para designar 'sonho' e 'visão' favorece desde logo a compreensão do modo como são encaradas as ideias de 'sonhar' e de 'ter visões' em estado de vigília. 'A expressão de 'sonho' articulou-se fundamentalmente à volta de três famílias lexicais, correspon-

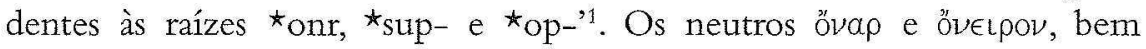
como o masculino óveı pos derivam da primeira e associam-se sobretudo à noção de 'imagem aparecida em sonho"2. $\mathrm{O}$ vocábulo útนos, que designa o

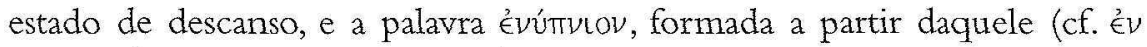

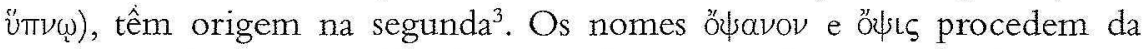
terceira e têm um significado mais abrangente do que o onírico, que destaca sobremodo o elemento visual observado pelo receptor durante a sua experiência, independentemente de ela acontecer quando está acordado

${ }^{1}$ M. R. Fernández, M. A. Vinagre (2003), “La terminología griega para 'sueño'y 'soñar'”, $C F C(L)$ 13: 71.

${ }^{2}$ Cf. P. Chantraine (1968), Dictionnaire étymologique de la langue grecque: histoire des mots. Paris, 802, s.v. övap.

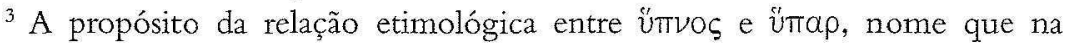
Odisseia é reiteradamente contraposto a ôvap para realçar o contraste entre 'sonho

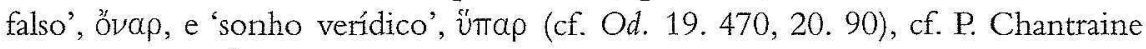
1968: 1157, s. v. ข็map. 
ou antes a dormir: 'vista, acto de ver, o que se vê, aparição' são possibilidades de significação apontadas por P. Chantraine, que não deixa de acentuar a ambivalência semântica dos termos (cf. 'acto de ver/ o que se vê') ${ }^{4}$.

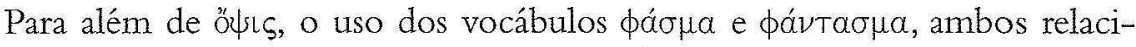

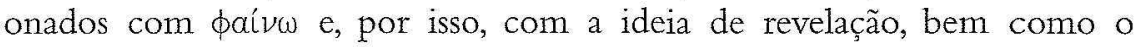

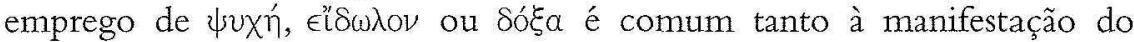
sonho como da visão, circunstância que ilustra a proximidade dos dois motivos também a nível linguístico. 'Ver' é pois uma sensação aliada a ambos os fenómenos, embora 'sonhar' implique visualizar algo durante o sono do indivíduo (cf. emprego habitual de termos como évútulov para designar 'sonho', seja sozinhos, seja a acompanhar outros, como ôvap e övelpov).

A épica, os Hinos Homéricos e a lírica furtam-se, de uma maneira geral, a expressar os substantivos referentes às visões, ao contrário do que costuma acontecer com os sonhos.

O cuidado de Heródoto em contar apenas o que resulta da observação dos factos, por seu turno, impele-o a servir-se usualmente de фáo $\mu a$

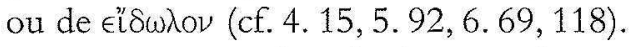

Com certa frequência, a produção trágica exime-se também de recorrer a qualquer um dos nomes antes mencionados quando descreve uma visão em estado de vigília; contudo, faz sentir o relevo concedido aos elementos visuais aí presentes, quer pelo emprego reiterado de verbos com o sentido de 'ver' (cf. A., Ag. 1125, 1217, 1246, Ch. 1061; E., Tr. 308, Ba. 918, 1095), quer através do recurso profuso e impressivo a nomes e adjectivos portadores de sensações cromáticas (cf. A., Ag. 1189, 1278, 1293, 1309, Ch. 1049, 1058; E., Ba. 1135). Saliente-se ainda que a predilecção notória de Eurípides por motivos visuais o incita a usar, de modo expres-

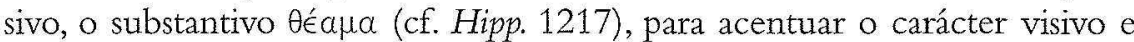
espectacular da manifestação de Posídon aos mortais.

No que diz respeito aos sonhos, é curioso notar que Heródoto utiliza com especial insistência o nome ơł $\$ \zeta$, isolado ou aliado a évútrvı ou a óveípov ${ }^{5}$, numa escolha que reflecte a habitual preocupação do historiador

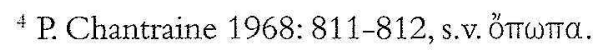

${ }^{5}$ Cf. A. M. Kessels (1978), Studies on the dream in Greek Literature. Utrecht, 196. M. Casevitz (1982), "Les mots du rêve en grec ancien", Kterna 7: 72, salienta que é em Heródoto que ơłıৎ aparece pela primeira vez com o sentido de 'visão onírica'. 
em encontrar uma explicação racional para tudo o que narra: o relato dos factos deve ser assente na visão ${ }^{6}$.

A tragédia prefere vocábulos derivados da raiz ${ }^{\star}$ onr, apesar de registar os restantes ${ }^{7}$, que parece fazer equivaler-lhes a nível semântico ${ }^{8}$, aliás como acontece com Aristófanes. Observe-se entretanto que Ésquilo, numa opção que espelha de algum modo a sua crença de que o mundo divino 'se mostra' ao homem através de sinais, faz uma utilização digna de nota de

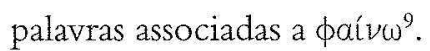

Para lá dos termos escolhidos para designar 'sonhos' e 'visões', os adjectivos, verbos e construções sintácticas que com eles se articulam de forma mais imediata ajudam a definir melhor o modo como aqueles dois fenómenos são concebidos.

Os epítetos com que a épica por vezes qualifica as experiências oníricas remetem em especial para o carácter divino das mesmas, de resto sublinhado já pela menção frequente ao nome do ente supra-humano responsável pelo envio daquelas aos mortais, ora Zeus, Atena ou Hermes,

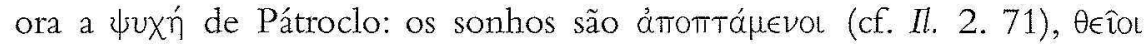

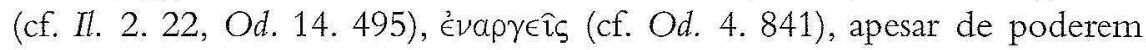
assumir uma natureza enganadora (cf. $\Pi$. 2. 81, «evoóc). Alguns atributos homéricos não deixam de aludir à natureza funesta de que as visões sonhadas podem revestir-se (cf. Il. 2. 6, oûגov, 10. 496, кakóv, Od. 19. 568, aìós), mesmo se tal compleição é preferencialmente destacada pela produção trágica, que realça ainda a debilidade própria daquele fenómeno, já mencionada também pela épica (cf. Od. 19.562).

A experiência de Penélope, no canto XIX da Odisseia (cf. 535 sqq.), salienta que os sonhos são 'impossíveis' e 'confusos' $(560)$, em consonância com o cepticismo manifestado pela própria receptora, quando confrontada com a predição do <ansiado> regresso de Ulisses.

${ }^{6}$ Cf. o facto de, na introdução que faz às Histórias, Heródoto definir a sua própria narrativa como i $\sigma$ Topía, entendida como 'testemunho visual' (cf. D. Asheri, V. Antelami (1997-4ª ed.), Erodoto. Le Storie I. Milano, xxvii; M. H. Rocha Pereira, J. R. Ferreira, M. F. Silva (1994), Heródoto. Histórias I. Lisboa, xix).

${ }^{7}$ Sobre este assunto, cf. M. R. Fernández, M.A.Vinagre 2003: 84 sq.

${ }^{8}$ A este propósito, cf. a multiplicidade de termos empregues por Sófocles para se referir ao sonho de Clitemnestra na Electra (cf. öłiv, 413, ővap, 425, oveípata, 460, фáouata (...) óveípwv 644-645).

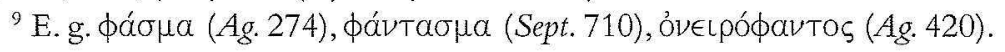


No canto IV do mesmo poema, o $\epsilon$ İ $\delta$ iोov que surge durante a noite sobre a cabeça adormecida da rainha de Ítaca, com o objectivo de a tranquilizar quanto à sorte de Telémaco (cf. 795 sqq.), é descrito como áuavpóv (824), atributo adequado a um fantasma, criado por Atena ex nihilo. Hécuba, na peça homónima de Eurípides, recorre por sua vez ao

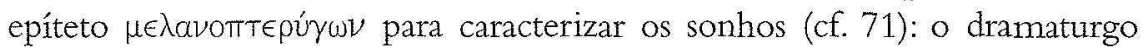
selecciona um vocábulo com uma notação cromática notável, ausente dos qualificativos que até ao momento se relacionam de forma directa com 'sonho', numa opção que dá mostras do seu gosto peculiar por elementos pictóricos, neste caso incrementadores do pathos da sonhadora. A terminologia usada pela velha rainha de Tróia é sintomaticamente parodiada por Aristófanes, em $R a .1331$ sqq., através de uma acumulação de adjectivos que insinuam a tonalidade negra e medonha da experiência onírica.

A adjectivação, em co-relação imediata com 'sonho', encontra ainda expressão, mesmo se escassa, em Píndaro, em Heródoto e noutros passos aristofânicos. $\mathrm{Na}$ verdade, Píndaro (Pi. 4. 289) recorre ao qualificativo

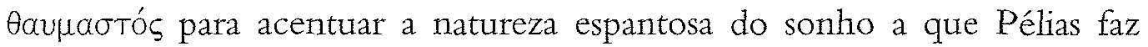
menção; o emprego daquele vocábulo é mais um elemento favorecedor do discurso persuasivo do rei para convencer Jasão a empreender a arriscada viagem à Cólquida. Aristófanes ( $V$. 13) retoma o mesmo atributo para definir de forma caricatural o sonho de um dos escravos que põe em cena, repleto de alusões políticas.

Heródoto, 1. 209 vale-se da noção psicológica que o qualificativo

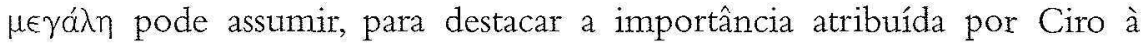
visão sonhada com que é confrontado. Aristófanes, em tom de paródia, põe na boca de um outro escravo de $V$ o neutro daquele adjectivo para descrever a sua experiência (cf. 28), que implica uma crítica a toda a vida política ateniense da época: à ideia de gravidade sublinhada pelo historiador, o comediógrafo sobrepõe a noção física de tamanho.

O carácter premonitório e verídico que em geral a tragédia esquiliana associa aos sonhos que descreve é sugerido através do recurso expres-

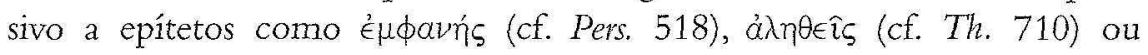
<OứTol> Hátalov (cf. Ch. 534).

Sófocles, na Electra, não deixa por seu turno de sublinhar a natureza ambígua das experiências sonhadas, de resto similar à dos oráculos que se

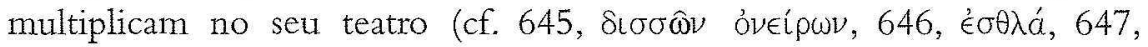
Éx$\theta p a ́)$. 
Eurípides atribui aos sonhos o tradicional carácter alado (cf. IT 571, $\pi т \eta \nu \hat{\omega} \nu)$, mas qualifica-os como 'falsos', no seguimento da experiência de Ifigénia na Táuride (cf. IT 569), depois de os ter classificado já como кaLvá (cf. IT 42).

Os termos 'sonho' e 'visão', na épica, estão ainda intimamente ligados a verbos sugestivos de movimento e de sonoridade, que ocorrem com mais abundância do que os adjectivos, decerto porque pertencem à classe gramatical que melhor reflecte o carácter activo e

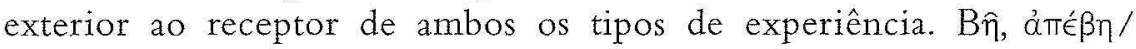

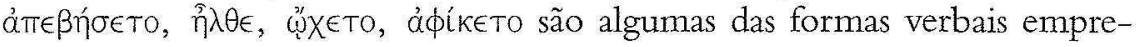
gues de modo recorrente para indicar a chegada e a partida da aparição divina para e de junto da figura que a observa (cf. Il. 1. 194, 2. 16, 17, 23. $65,101,24.121$, Od. 1. 319, 4. 450, 11. 150, 13. 221, 14. 495, 20. 55). 'Sonhar' e 'ter uma visão' equivalem assim, na poesia homérica, a 'ser visitado por uma entidade transcendente'.

A presença constante de expressões e fórmulas como $T \hat{\varphi} \mu \nu$

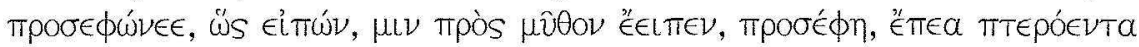

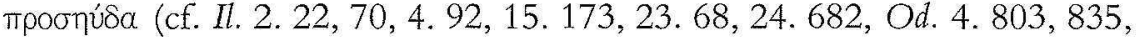
10. 280) traduz a valorização concedida ao discurso da aparição, que faz relegar para um plano secundário o elemento visual dos sonhos e das visões, ao contrário do que é comum acontecer na tragédia e em boa parte dos exemplos herodotianos e aristofânicos. De facto, à sucessão de imagens habitual na descrição destas experiências, o modelo homérico sobrepõe por norma uma visão estática e estereotipada, que a insistência em expressões formulares do tipo $\sigma \tau \hat{\eta} \delta$ ' inè $\kappa \in \phi a \lambda \hat{\eta} \varsigma$ ou $\kappa \in \phi \alpha \lambda \hat{n} \phi L \nu$

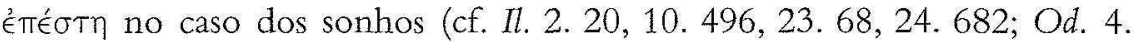

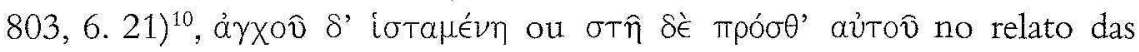
visões (cf. Il. 2. 172, 4.92, Od. 15. 9) permite evidenciar. No entanto, os prefixos e os advérbios associados às formas verbais representativas da natureza mais ou menos fixa da visão deixam perceber que, enquanto as figuras oníricas costumam posicionar-se sobre a cabeça de um sonhador adormecido, as aparições que surgem a um receptor em estado de vigília se colocam, de preferência, diante dele, admitindo o contacto físico entre

10 Segundo A. L. Oppenheim (1956), "The interpretation of dreams in Ancient Near East", TAPhS 46.3: 189, relatos de sonhos sumérios, acádicos e hebraicos usam expressões similares. 
ambos (cf. Il. 1. 197, 361, 3. 385, 24. 127). Os dois fenómenos são encarados sobretudo como meios de transmitir oralmente uma mensagem precisa a um receptor determinado, que o conduza a um comportamento consonante com o discurso ouvido, pelo que a sua formulação é em geral explícita e o tom sobremodo exortativo (cf. presença constante de vocativos (e.g. Il. 2. 23, 23.69, 24.683, Od., 4. 804, 2. 402), de verbos no imperativo (e.g. Il. 2. 33, 23. 71, 75, Od. 4. 825, 6. 30), de frases interrogativas (e.g., Od. 2. 173-175, 4. 804, 6. 22-23) ${ }^{11}$. O carácter concreto por norma atribuído ao conteúdo dos sonhos e das visões épicas justifica que as sensações visuais percam terreno para as auditivas, uma vez que é nas palavras da aparição que se condensa o cerne da mensagem divina, por hábito furtiva a metáforas ou a imagens ${ }^{12}$.

Nos sonhos, o relacionamento entre a figura onírica e o receptor é mais distante do que nas visões, e o espaço concedido ao diálogo é diminuto, ou pelo menos pouco permissivo a uma consulta dos humanos aos desígnios do mundo transcendente. Nas visões em estado de vigília, o contacto físico próximo entre a aparição e o indivíduo que está acordado proporciona com frequência o confronto verbal, seja para o receptor se justificar de algum reparo, seja para proclamar certa indignação ou hesitações.

A percepção das visões como um fenómeno exterior ao receptor parece evidente também nos Hinos Homéricos, em boa parte da lírica, em várias experiências descritas por Heródoto 'à maneira tradicional épica' e ainda em alguns exemplos relatados por Aristófanes.

Em termos linguísticos, os Hinos Homéricos a Afrodite e a Deméter recorrem a formas verbais indicadoras da mobilidade das aparições, que tomam um aspecto humano e conversam com os mortais (cf. h. Hom. Aphr.

${ }^{11}$ Cf. Hdt., 7. 12-18: para lá da clareza aparente da mensagem veiculada, os sonhos de Xerxes e o de Artabano assumem um tom exortativo evidente, que constitui mais um elemento a aproximá-los da tradição épica.

${ }^{12}$ Todavia, os símiles desenvolvidos que, no dizer de G. S. Kirk (1962), The songs of Homer. Cambridge, 345-346, 'intervêm com regularidade para animar a acção de exércitos, indivíduos ou divindades ${ }^{13}$, estão por vezes ao serviço das visões em estado de vigília, sobretudo para realçar a chegada ou a partida dos entes divinos <de $>$ junto dos mortais, bem como para sublinhar a actuação do homem em consequência da visão (cf. Il. 5.136 sqq., 14. 148 sqq., 15. 263 sqq., 17. 547 sqq., 22. 22 sqq.). 


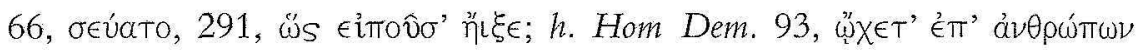

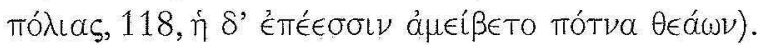

Em Safo, tal sensação manifesta-se pelo uso do vocativo com que se dirige às personagens visionadas (cf. fr. 63 L.-P. 1), ou pelos verbos cinéticos que lhes associa (cf. fr. 63 L.-P. 2, фoítaıs), assim como pelo diálogo que o sujeito poético intenta ou trava de facto com as aparições (cf. fr. 63, 134 L.-P.) ${ }^{13}$.

O fr. 47 P. de Álcman sugere também a modalidade presente nos

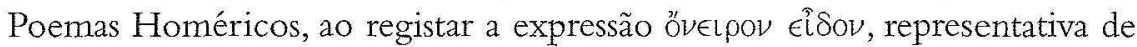
que a figura de Febo surge em sonhos ao receptor.

Os verbos empregues por Píndaro acentuam que a experiência não é interna a quem a recebe, mas vem antes do exterior (cf. P. 4. 163, i $\omega े \nu$

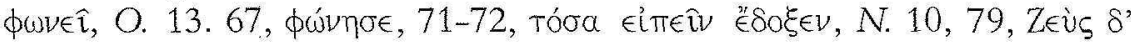
ávTíos ที่ $\lambda v \theta \epsilon ́$ oi).

No caso das Histórias, e também da maior parte dos exemplos aristofânicos, a insistência habitual no verbo Soké $\omega$ para aludir à visão ocorrida (e.g. Hdt., 1. 108, 3. 30, 124, 5. 56, 6.117; Ar., Eq. 1090, 1092, V. 15, 31, 42) deixa perceber que o receptor entende que a mensagem e/ ou as imagens com que se depara the sobrevêm de fora (aliás como acontece já no fr. 219 da Oresteia de Estesícoro, alusivo ao sonho de Clitemnestra). O relato da esposa de Aríston, nas Histórias (6.69), tal como o testemunho de Xerxes perante Artabano (7. 15), são além disso ilustrativos de que muitas experiências herodotianas se aproximam das homéricas no que toca

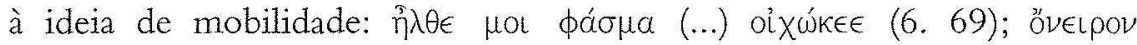

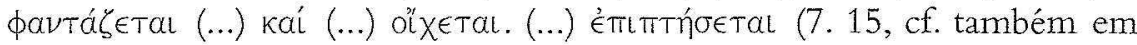
especial 7.17). A realçar esse parentesco está a referência à posição ocupada pelas figuras oníricas, sobre a cabeça do sonhador, e ao discurso por

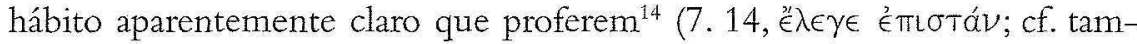

13 Nos Anacreontea, verbos dinâmicos acompanham por norma as visões, sugestivos do combate contínuo e doloroso que o poeta trava com o Amor, entendido em simultâneo como um elemento externo ao receptor e como um sentimento intrínseco. A proximidade entre o sujeito poético e a aparição é tal que implica constantemente o contacto fisico entre ambos.

${ }^{14}$ A este propósito, é curioso observar que Heródoto, em 1.34, substitui o convencional $\lambda \dot{\epsilon} \gamma(\omega)$ por $\phi a i ́ v \omega$, talvez mais relacionado com a noção de destino humano que o historiador por certo quer evidenciar. 
bém 1. 34, 2. 141, 5. 56, 6. 105, 7. 12, 17), para lá de alguns dos sonhos das

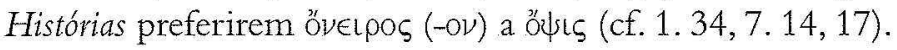

Aristófanes, em Cavaleiros, dá testemunho da tradicional personificação do sonho na épica, pela repetição expressiva, na parte final dos versos

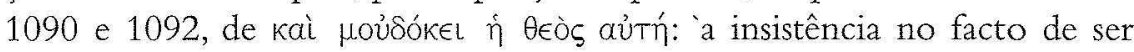
Atena em pessoa a actuar, no sonho, sobre personagens simbólicas da vida política ateniense da época enquadra-se contudo no espírito crítico da comédia antiga e constitui decerto motivo de cómico. A natureza exterior ao indivíduo que sonhos e visões convencionalmente assumem está patente na resposta da deusa Íris a Pistetero: "Vou ao encontro dos mortais, da parte de meu pai, para lhes dizer que façam sacrificios aos deuses olimpicos..." (Av. 1230 sqq. $)^{15}$. Nas Nuvens, porém, o comediógrafo recorre

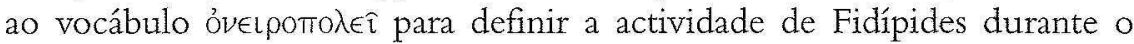
sono $(16,27)$, num registo de alguma forma ilustrativo do desenvolvimento do motivo onírico, que surge como uma projecção da consciência do homem.

A produção trágica serve-se por norma de vocábulos e expressões que definem sonho e visões em estado de vigilia como fenómenos exteriores ao ser humano, mesmo se por vezes aspectos psicológicos do indivíduo parecem interferir no tratamento daqueles motivos, provocando uma fusão entre elementos intrínsecos e extrínsecos. Uma tal aliança deixa entrever o caminho evolutivo desse tipo de experiências, entendidas como despoletadas pelo mundo exterior, mas afinal sentidas já como um reflexo das preocupações e da consciência humanas (cf. o caso de Menelau, no Agamémnon esquiliano, ou o de Orestes, na peça homónima de Eurípides). A par do verbo Sokéw para introduzir a descrição dos sonhos (cf. A., Pers. 181, Ch. 527; E., IT 44), surgem outros, evocativos das visitas sonhadas da

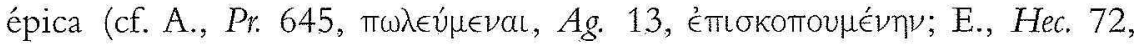
ámоте́ $\mu т о \mu a \imath)$. No caso da experiência de Io (cf. A., Pr. 645 sqq.), não falta sequer o discurso exortativo habitual, orientado pelo propósito concreto de instigar a jovem a unir-se a Zeus, circunstância que justifica a abundância de termos e expressões oriundos do foro amoroso (cf. 648, ráuou,

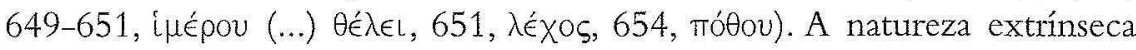
das visões em estado de vigília é sugerida ora por verbos dinâmicos (cf. A.,

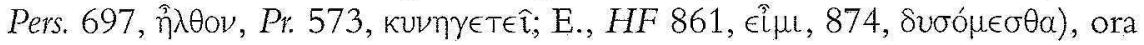

\footnotetext{
${ }^{15}$ Trad. de M. F. Silva (1989), Aristófanes. Aves. Lisboa.
} 
pela invocação directa do mundo divino aos receptores visados (cf. S., $A j$.

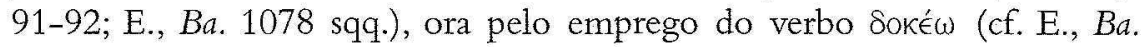

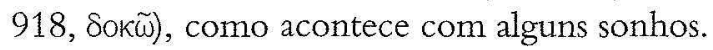

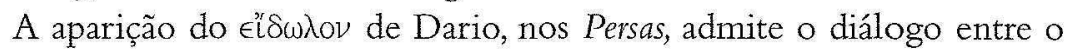
antigo rei, Atossa e o coro, com uma série de questões e de respostas, num episódio ilustrativo de que a visão é exterior aos receptores. Naturalmente, nesta cena, as palavras do espectro sobrepõem-se aos elementos visuais, uma vez que é para ouvir os seus conselhos avisados < e determinadas predições $>$ que os anciãos persas o invocam.

Embora na épica o modelo convencional das visões oníricas e em estado de vigília exiba uma figura que surge a um receptor e the fala, os próprios Poemas Homéricos admitem já a descrição de uma experiência sonhada em termos enigmáticos, modalidade que encontra também expressão em qualquer um dos géneros literários considerados na presente análise. Todavia, é na historiografia herodotiana e na produção trágica que ganha particular relevo, uma vez que a obscuridade da linguagem se adequa na perfeição ao destaque concedido por ambos os géneros ao confronto do homem com o próprio destino, o qual por hábito o indivíduo é incapaz de compreender. Deste modo, a experiência relatada por Penélope em Od. 19. 535 sqq. aproxima-se mais de vários sonhos das Histórias e da tragédia ática do que da tradição épica, seja pela natureza premonitória e simbólica, propícia a uma decifração subsequente, seja ainda pela atenção concedida aos elementos visuais, em detrimento dos auditivos. Tal semelhança implica que predomine uma linguagem ambígua, porquanto reveladora do futuro, parcialmente inspirada no mundo animal relacionado com a vida doméstica. Legitima-se assim o comentário de $\mathrm{E}$. Lévy ${ }^{16}$, ao advogar que 'se a Ilíada não parece privilegiar muito o aspecto premonitório do sonho, na Odisseia a revelação tem tendência a levar a melhor sobre a injunção'. A experiência da rainha prenuncia algo positivo e mesmo ansiado, ao contrário do que é habitual nas Histórias e na tragédia, e pese embora o cepticismo que Penélope demonstra perante a natureza obscura daquilo que sonha. É curioso notar como a mesma figura que se deixa convencer pelo $\epsilon \mathfrak{t} \delta \omega \lambda$ ov divino que lhe aparece sob a forma da irmã, Iftime (cf. Od. 4. 795 sqq.), manifesta mais tarde relutância

${ }^{16}$ (1982), "Le rêve homérique", Ktema 7:39. 
perante os símbolos sonhados com que se depara (cf. importância acordada ao discurso das aparições oníricas na épica, bem como à persuasiva forma humana que por hábito tomam).

A simbologia animal marca igualmente presença no $h$. Hom. Dion. (cf. 7.44 sqq.): inábeis para perceber a natureza ilusória da figura antropomórfica que capturam, os piratas apenas se atemorizam diante da incarnação bestial de Dioniso num leão aterrador, a melhor forma encontrada pelo deus para se revelar aos efémeros (cf. 7.2, o emprego significativo de

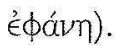

Em Estesícoro, os símbolos animais merecem também destaque, embora em conexão com outros, oriundos do mundo humano (cf. fr. $42 \mathrm{P}$ ): os gansos domésticos do sonho de Penélope e a águia representativa do poder são substituídos por uma criatura ctónica, a serpente, adequada à atmosfera de morte que paira no sonho de Clitemnestra, tal como acontece depois nas Coéforas de Ésquilo (cf. 527 sqq.). Se, no passo lírico,

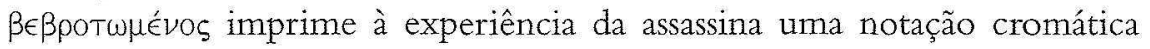
denunciadora de violência e desgraça, o dramaturgo insiste, por sua vez, na noção constante na Oresteia de que sangue derramado exige novo sangue: através do recurso a uma imagem poderosa em termos visuais, que joga com uma hábil oposição de tons, mistura o branco do leite materno e o vermelho sanguíneo provocado pela cria que morde o peito alimentador (cf. 533), numa fusão inesperada e indesejada pela receptora onírica, para quem o próprio filho e herdeiro do trono se converte em assassino impiedoso.

Nas Histórias, para lá de uma alusão à águia dominadora, na descrição da figura alada de Dario sonhada por Ciro (1. 209), um outro animal selvagem, o leão dado à luz no sonho de Agarista (6. 131), prenuncia simbolicamente o poder de figuras predestinadas para reinar, seja na Pérsia

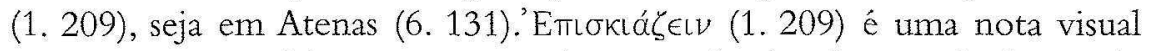
registada por Heródoto para intensificar o esplendor do reinado futuro de Dario, capaz de 'cobrir de sombra', pelo sucesso das suas campanhas militares, continentes inteiros, como a Ásia e a Europa. Para Epizelo, ao

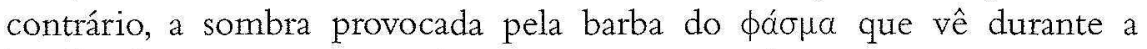
batalha de Maratona pressagia a cegueira que em breve o toma e a morte de um companheiro de combate (6.117). Deste modo, como os sonhos, também as visões em estado de vigília podem ligar-se nas Histórias a uma linguagem metafórica, que é preciso decifrar.

Aristófanes associa os símbolos animais ao poder, conferindo-lhes embora um sentido depreciativo, apropriado ao tom crítico da sua comédia 
em relação aos políticos da época na democracia ateniense. Nessa perspectiva, valoriza atributos da águia e de um enorme cetáceo, como representativos da avidez ( $V .15-19,31-41)$, em detrimento da imagem de poder que ambos representam. $O$ diálogo estabelecido entre o sonhador, que descreve a própria experiência, e a testemunha-intérprete do relato, pouco comum na épica e mesmo em Heródoto, permite decifrar 'em directo' e de forma crítica a figura visada pelo símbolo, ora Cleónimo ( $V .20-23)$, ora Cléon (V. 38), proporcionando motivo de cómico. Aristófanes satiriza, por outro lado, a subserviência dos cidadãos comuns perante os governantes, imaginando-os como dóceis carneiros que se deixam convencer na assembleia por demagogos (V. 31-41). Os lugares públicos de Atenas onde decorrem os sonhos descritos pelos dois servos são naturalmente um cenário adequado para a crítica política. $O$ comediógrafo parodia também o tom inflamado dos discursos de um orador em particular, Cléon, postos a ridículo seja pela comparação desabonatória com a voz de uma javalina em chamas, seja pelo emprego de interjeições sugestivas de desagrado (37, aißỗ), seja pelo uso consecutivo de verbos no imperativo (36), seja pelo recurso a sensações olfactivas (38), expressivas da repulsa causada pelas palavras do demagogo. De resto, a sinestesia perceptível no relato do sonho de Sósia evidencia com oportunidade a relevância do assunto descrito: ao abarcar 'toda a nau do estado'(29), é compreensível que concorram em simultâneo na sua experiência sensações visuais, auditivas e olfactivas. Aristófanes recorre ainda à noção de mau agoiro que o corvo pode assumir, para censurar um adulador de Cléon, Teoro ( $V$.42-45).

Além da política, também a literatura contemporânea, en especial a tragédia euripidiana, instiga o comediógrafo a exprimir-se através de símbolos animais sonhados, desta feita provenientes da vida doméstica, para acentuar o contraste entre a enorme angústia da sonhadora e o respectivo motivo, a perda de um galo ( $R a .1331$ sqq.), numa crítica evidente às cenas de grande intensidade emotiva, frequentes em Eurípides. Nomes como 'obscuridade', 'Noite', 'Hades', 'mortalha', 'defuntos', adjectivos do tipo 'negra', 'terrível', verbos como 'arrepiar', interjeições e invocações várias constituem uma forma de Aristófanes caricaturar traços convencionais do sonho trágico, também em termos de linguagem.

Os mundos vegetal e humano são igualmente fonte de inspiração para os sonhos simbólicos da historiografia e da tragédia, sendo que quer Heródoto, quer Ésquilo, Sófocles e Eurípides revelam uma preferência 
especial pela presença da componente humana nos mesmos, ainda que combinada com elementos retirados dos domínios animal e vegetal. Tal opção liga-se por certo à valorização crescente concedida ao homem na época clássica. Em geral, em Heródoto, essas experiências anunciam ao próprio sonhador a sua substituição no poder, num espaço de tempo mais ou menos longínquo (Hdt., 1. 107, 108, 209, 3. 30), de resto como acontece também na Electra sofocliana, onde o loureiro que rebenta do ceptro real indicia a subida ao trono de Micenas do seu herdeiro legítimo, o jovem Orestes (cf. 417 sqq., o sonho de Clitemnestra). A vitalidade da natureza adequa-se a exprimir a pujança do príncipe e a sua predestinação para governar o reino que por direito lhe pertence.

Ésquilo, nas Coéforas, apostado em demonstrar que um crime de sangue exige castigo, escolhe para o sonho de Clitemnestra um animal simbólico que ela própria amamenta, a serpente (cf. 527 sqq.), capaz de vingar o assassínio cometido pela rainha, numa antecipação do comportamento de Orestes regressado do exílio (cf. 527 sqq.). Nesta perspectiva se compreende o concretismo da experiência sonhada pela filha de Tíndaro, a cuja descrição não faltam termos relativos à anatomia humana (531,

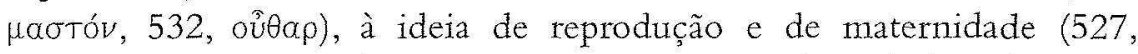

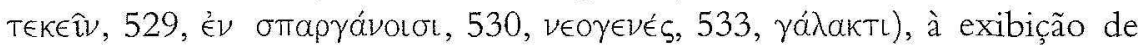

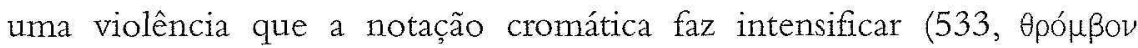
aінатоs).

O mundo animal serve ainda de fonte de inspiração para Ésquilo noutros sonhos: além da referência a uma animada perseguição de caçadoras divinas à vítima que almejam, espelhada no recurso repetido ao imperativo, indicador da tentativa de aprisionar a caça (Eu. 130, $\lambda \alpha \beta \in$ ) , bem como no emprego de termos próprios da actividade venatória ( $E$ u. 147,, $\mathcal{E} \xi$

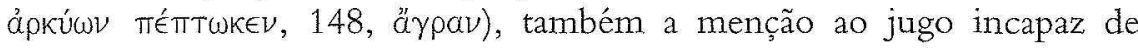
submeter com igual sucesso duas belas mulheres procede do domínio animal (Pers. 192 sqq.). Substantivos tradutores de actividade (Pers. 188, Eu. 139), verbos dinâmicos (cf. Pers. 195-197, Eu. 130,131, 137 sqq.), a profusão de copulativas (Pers. 194-196) ou, pelo contrário, o assindetismo (Eu. 130) são elementos que testemunham o carácter movimentado que se associa às imagens de ambos os sonhos, susceptível de inquietar per se o receptor. Nas Euménides, a ideia de perturbação é ainda sugerida pelos roncos repetidos das Erínias, a partir do v. 117: o espectro de Clitemnestra, ao ouvir as divindades, assemelha-as de modo sintomático a "um cão que 
não larga a preocupação da sua busca" (130-131) ${ }^{17}$. Nos Persas, as sensações cinéticas combinam-se de forma hábil com outras de natureza visual, que sublinham o porte distinto da 'parelha' destinada ao jugo (181 sqq.), numa nota ajustada ao espírito dos governantes orientais, muito dados à ostentação da prosperidade.

Em Eurípides, os elementos visuais perceptíveis nos sonhos de Ifigénia e de Hécuba são evidenciados por verbos denunciadores de uma captação feita através do olhar (IT 47, Hec. 90), bem como por nomes e/ou adjectivos cromáticos, portadores de maior impressividade e verosi-

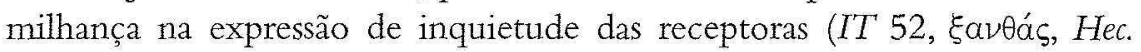
90, aífovt). O relato de Ifigénia, vibrante de um movimento destruidor (cf. 46 sqq., a sucessão de verbos indicadores de sensações cinéticas), é 'iluminado' durante breves momentos pelo tom dourado dos cabelos que a sonhadora identifica como pertencentes a Orestes. No entanto, a filha de Agamémnon interpreta de modo crrado essa luz libertadora que se vislumbra no meio do desabamento do palácio de Argos, entendendo-a como um prenúncio da morte do irmão. A escolha oportuna do motivo arquitectónico para representar Orestes como o último sustentáculo da casa real argiva evoca o fascínio exercido em Eurípides pelas artes plásti$\mathrm{cas}^{18}$, ou antes, pelo que é visível aos olhos do homem.

O colorido presente no sonho de Hécuba é bem diferente do que ocorre no de Ifigénia, e tem de algum modo paralelo no relato do sonho do auriga de Reso (cf. E., Rh. 780 sqq.): em ambos os casos, é o vermelho sanguíneo a captar a retina do espectador (Hec. 90, Rh. 791), transmitindo-lhe 'visualmente' a agonia das personagens. Na Hécuba, o vermelho combina-se com a tonalidade negra atribuída aos sonhos (71), incrementando de forma poderosa a dor cantada pela velha rainha de Tróia numa monódia angustiada, que encontra nas trevas um motivo adequado para expressar a intensidade profunda do sofrimento ( $c f .59-97$, a profusão de termos relacionados com noite, obscuridade, morte). $O$ gosto do dramaturgo pelo patético leva-o a imaginar, para ambas as experiências, lobos ferozes que abatem sem piedade vítimas indefesas, sejam elas a corça

${ }^{17}$ M. O. Pulquério (1998), Ésquilo. Oresteia. Lisboa. As traduções da Oresteia são citadas desta versão.

${ }^{18}$ Sobre este assunto, cf. M. F. Silva (2005), "Elementos visuais e pictóricos na tragédia de Eurípides", Ensaios sobre Eurípides. Lisboa, 284-395. 
matizada do sonho da velha rainha troiana, ou antes os cavalos presentes na experiência descrita pelo auriga. Uma vez mais, os animais surgem no sonho em conexão íntima com figuras humanas, em particular com os próprios receptores, cuja angústia o poeta se mostra empenhado em realçar: na verdade, tanto Hécuba como o auriga se manifestam desesperadamente impotentes para alterar as circunstâncias dolorosas que vivenciam.

A ambiguidade de linguagem é uma característica recorrente também em boa parte das visões em estado de vigília relatadas pela tragédia, apropriada para questionar o homem sobre a diferença entre aparência $\mathrm{e}$ realidade, que em geral os mortais comuns não conseguem distinguir com clarividência. No Agamémnon, Cassandra reconhece a natureza enigmática da descrição que faz ao coro (1183), reveladora de um destino atroz e iminente para o Atrida e para si própria, sorte que ela mesma se encarrega de desvendar. O palácio de Argos, "matadouro de homens" (1092), o banho fatal de Agamémnon, as malhas que o enlaçam mortalmente, as mãos traiçoeiras de Clitemnestra, "fềmea assassina do macho" (1231-1232), vaca, cadela, "uma anfísbena, outra Cila" (1233), uma "leoa de dois pés" (1258-1259), as crianças mortas "que seguram as vísceras, os próprios intestinos" (1221-1222), o leão cobarde que prepara a vingança contra os recém-chegados de f́lion, o cepo pronto para o sacrificio, o vingador anunciado, são a expressão, "através de véus" (1179), do fim trágico destinado a Agamémnon <e a si própria>, penosamente antevisto pela profetisa. $O$ realismo tremendo da visão aterradora leva Cassandra a irromper numa série de interjeições, invocações e interrogações sugestivas do horror que sente, e que o cromatismo e a sonoridade dos vocábulos "de sinistro augúrio" (1078) que profere ajudam a intensificar.

De igual modo dolorosa é a monódia entoada, numa linguagem obscura, pela Cassandra euripidiana de Troianas: o colorido que anima o canto com que entra em cena é distinto daquele presente no Agamérnnon, desde logo porque não reflecte uma expressão simultânea à ocorrência da visão, como em Ésquilo, mas antes a reacção posterior da princesa troiana. $\mathrm{Na}$ verdade, ao vermelho pressago, anunciador de morte na primeira peça da Oresteia, sobrepõe-se o brilho luminoso e festivo dos archotes nupciais, aliado a uma dança frenética, celebrativa de fatídico casamento. Através da alegria manifestada nas palavras, Cassandra dissimula o sofrimento que

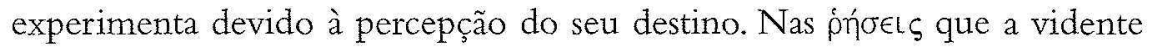
dirige à mãe e a Taltíbio, reveladoras de parte do conteúdo da visão, evidencia-se já o tom ominoso resultante das imagens observadas (cf. 357, 


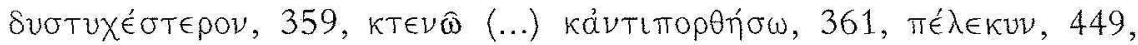

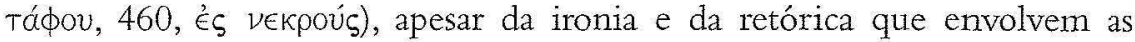
palavras da profetisa: menos plástica do que a visão de Cassandra no Agamémnon, a da homónima euripidiana não é contudo menos densa de emoção.

As experiências de Orestes após o matricídio, em Ésquilo como em Eurípides, são marcadas por cores sombrias, denunciadoras do horror infundido no receptor pelas Erínias sanguinárias, semelhantes a serpentes e a cadelas monstruosas. O retrato daquelas divindades repelentes afigura-se claro para o príncipe argivo, mas as personagens que testemunham a sua descrição mostram certa incapacidade para compreender de modo eficaz a linguagem de Orestes, e associam-na ao delírio, estado que nos exemplos euripidianos ganha contornos patológicos, sugeridos pela profusão de termos ligados à medicina da época ${ }^{19}$. No Orestes, o tratamento do motivo das visões indicia ainda uma preocupação crescente com a psicologia do indivíduo, bem espelhada na resposta do filho de Agamémnon a Menelau,

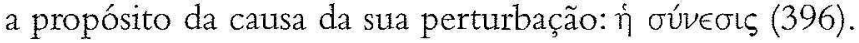

A visão de Penteu nas Bacantes (cf. 918-922) é ilustrativa do carácter enigmático que a linguagem pode assumir na abordagem daquele fenómeno, assim como da falta de perspicácia habitual no homem para o entender: a luz de dois sóis, a imagem dupla da cidade que o neto de Cadmo governava com orgulho, a percepção de Dioniso como um touro são elementos simbólicos de uma realidade que abre caminho ao verdadeiro conhecimento, mas que o jovem monarca de Tebas é incapaz de interpretar de forma correcta.

Recorrente nas Bacantes, porquanto representativo da própria essência humana e da natureza selvagem da religião dionisíaca, que a peça teima em realçar, o simbolismo animal ganha particular relevo na visão de Agave e das ménades 'entusiasmadas' que celebram Brómio no cimo do Citéron (cf. 1043 sqq.). Na crença de que Penteu é um leão a abater, as mulheres tebanas imolam o filho de Agave, por ironia, convertida em sacerdotisa do ritual monstruoso. Elementos pictóricos, à mistura com sensações auditivas e cinéticas, bem como comparações expressivas da crueldade do episódio

${ }^{19}$ A este propósito, cf. J. R. Porter (1994), Studies in Euripides' Orestes. Leiden, New York and Köln, 299-300; H. W. Miller (1944), "Medical terminology in tragedy", TAPhA 75: 156 sqq. 
reflectem de forma notável e impressiva a violência e a brutalidade do espectáculo macabro, ilustrativo do poder do filho de Sémele.

O carácter sobremodo funcional dos sonhos e das visões épicas, reflexo de um pensamento arcaico que concede primazia aos deuses e à forma soberana como interferem na vida dos efémeros, dá progressivamente lugar a experiências mais centradas no homem e no seu destino, que assumem não raro uma natureza profética e/ ou preditiva. $O$ progresso dos sonhos e das visões, do divino para o psicológico, resulta assim de uma evolução na perspectiva com que o ser humano encara a própria existência. A expressão poética acompanha este movimento, sobrepondo à mensagem épica, por norma directa e formulada em termos claros, uma linguagem simbólica ou enigmática, presente já em Estesícoro, em Heródoto e, de forma insistente, na produção trágica.

\section{Bibliografia ${ }^{20}$}

\section{Edições, traduções e comentários}

D. Asheri, V. Antelami (1997- $4^{2}$ ed.), Erodoto. Le Storie I. Milano.

J.R. Porter (1994), Studies in Euripides' Orestes. Leiden, New York and Köln.

M. O. Pulquério (1998), Ésquilo. Oresteia. Lisboa.

M. H. Rocha Pereira, J. R. Ferreira, M. F. Silva (1994), Heródoto. Histórias I. Lisboa.

M. F. Silva (1989), Aristófanes. Aves. Lisboa.

\section{Estudos}

M. Casevitz (1982), "Les mots du rêve en grec ancien", Ktema 7: 67-73.

P. Chantraine (1968), Dictionnaire étymologique de la langue grecque: histoire des mots. Paris.

M. R. FernáNDeZ, M. A. Vinagre (2003), "La terminología griega para 'sueño' y "soñar", CFC(L) 13: 69-104.

A. M. KeSSELS (1978), Studies on the dream in Greek Literature. Utrecht.

G.S. KIRK (1962), The songs of Homer. Cambridge.

E. Lévy (1982), "Le rêve homérique", Ktema 7:23-41.

${ }^{20}$ Refere-se apenas aos títulos citados no presente artigo. 
H.W. Miller (1944), “Medical terminology in tragedy”, TAPhA 75: 156-167.

A. L. Oppenheim (1956), "The interpretation of dreams in Ancient Near East", TAPhS 46.3: 179-360.

M. F. Silva (2005), "Elementos visuais e pictóricos na tragédia de Eurípides", Ensaios sobre Eurípides. Lisboa, 284-395. 